\title{
Integrating career development into an undergraduate IT curriculum at an Australian University
}

\author{
Sophie McKenzie ${ }^{1}$ (D) Jo Coldwell-Neilson ${ }^{1} \cdot$ Stuart Palmer $^{2}$
}

Received: 22 March 2021 / Accepted: 23 April 2021 / Published online: 11 May 2021

(c) The Author(s), under exclusive licence to Springer Science+Business Media, LLC, part of Springer Nature 2021

\begin{abstract}
Career development is a multifaceted, life-stage-dependant and discipline-specific process that is difference for every decision maker. During their time at university, students are building upon their career choice through discipline-specific activities yet many still find the transition into the workforce problematic, particularly for those in the discipline of IT. With the varied nature of the labour market in Australia, it is more important than ever before for universities to assist students in their career development through various opportunities for career education. With this in mind, this research asked: What career development model, and curriculum recommendations, can support IT students to be better prepared for life after university to achieve their graduate outcomes? To answer this, this research will present how career education has been implemented in undergraduate IT education at Deakin University in Australia. In addition, this paper demonstrates how a career development model together with appropriate curriculum resources can assist in addressing students' career needs, specifically for the IT context. The model will help educators' better support students to build their career interest and navigate the changing labour market.
\end{abstract}

Keywords Information technology · Higher education · Career development · Graduate outcomes

\section{Introduction}

Higher education around the world is experiencing continued pressure to design curricula that will produce graduates who are able to self-manage their career and be ready to enter the workforce (Bennett et al., 2016; Carbone et al., 2015; Higher Education Academy, 2015; Nghia et al., 2020; Qenani et al., 2014; Samarasekera, 2012;

Sophie McKenzie

sophie.mckenzie@deakin.edu.au

1 School of Information Technology, Deakin University, Geelong, VIC, Australia

2 WorkSafe Victoria, Geelong, VIC, Australia 
Yorke, 2004). Management and consulting firm Korn Ferry (2018) argue that the workforce of the future will rely heavily on digital technology, requiring all workers to consider digital skills as a part of their career. Industry 4.0, with its focus on artificial intelligence and data science, will also have an impact on the skill requirements of workers (Australian Government, 2019; Deloitte, 2020; LinkedIn, 2020). The labour market of the future will see growth in productivity through digital technologies and skills, driving forward work force changes as the result of COVID-19 (Deloitte, 2020; U.S. Bureau of Labour Statistics, 2021).

Since 2015 there has been continued growth in the number of positions available in the Information Technology (IT) industry. The 2020 Digital Pulse report by Deloitte (2020) stated that the IT workforce increased 6.8\% from 2018 to 2019, which is more than double the increase recorded in other areas of the labour market. For IT graduates in Australia, their labour work-force participation in 2019 was a 93.8\% (QILT, 2020). Overall, in 2019 there were 772,100 IT workers, with 1,000,000 expected by 2027 (Deloitte, 2020). This trend is also shown in other parts of the world, with the U.S. Bureau of Labour Statistics stating that between 2019 and 2029 the IT industry is projected to grow by 11\%, much faster than other areas (U.S. Bureau of Labour Statistics, 2021). The job role in IT in Australia that received the most growth during in 2019 was IT professional worker (Deloitte, 2020). Over 30\% of those who work in IT in Australia are between the age of 35-44, which is higher than other professional areas, yet just less than half the workforce in-flow in 2019 were IT graduates. This highlights that IT graduates may not persist working in the industry by age 35 , opting to use their digital skills in other professions. Overall by $2025,73,700$ workers with an undergraduate IT degree will be required to meet the needs of Australian IT industry. This requires Australian Universities to increase the number of undergraduate IT graduates who complete their studies.

Industry 4.0 and the need for digital skills requires IT students to have the ability to self-regulate their career development to meet the demands of changing employment opportunities. Knowing how to construct career competencies, and navigate construction of career identity, in the evolving employment environment is critical for success of a worker in the twenty-first century (Greenhaus et al., 2008). A recent report by FYA (2021) highlighted the increase in flexible work arrangement for young people, regardless of discipline, demonstrating the ongoing need to develop a person's career decision making ability and employability skills. This was emphasised in QILT (2020) with less recent graduates reporting working full-time in 2019, demonstrating that younger and less experienced persons fare worse in challenging labour markets conditions. Deloitte recently reported that to address the skills gap universities will play a critical role to provide skilled IT workers for the Australian workforce (Deloitte, 2018). This trend is also being seen in other developed countries, with national frameworks directing career development initiatives in higher education (Nghia et al., 2020).

A career can be thought of as an occupation undertaken for a significant period of a person's life, constructed through a personal yet multi-faceted process, shaped by interactions amongst beliefs, behaviours, personal, interpersonal, societal, and environmental factors (Hall, 2002; Patton \& McMahon, 2006). During their time at university, students need to identify and prepare for their 
chosen career path by navigating through a variety of experiences that align with their personal career goals. To do this students need to be able to manage their own career development, however Jackson and Edgar (2019) found that student engagement with career services and interventions during their time at university can often be poor. While a variety of career development models exist in the literature (Bandura, 1986; Crites, 1973; Farmer, 1985; Hackett \& Betz, 1981; Holland, 1985; Lent et al., 1994; Parsons, 1909; Super, 1980), their application within the university curriculum is often varied (Watts, 2005).

In this study, the career development model implemented during the period of this study (2013 to 2018), expands on Social Cognitive Career Theory (SCCT) (Janz \& Nichols, 2010; Lent et al., 1994) by adding 'identity' as a component to assist career choice. In brief, “young people generate career interests by developing confidence in activities related to the interests (i.e. self-efficacy) and by learning that outcomes for them are contingent on the effort expended (i.e. outcome expectations)" (McKenzie et al., 2017b). As interests develop, young people set related career goals and self-regulate their behaviour towards these goals (Janz \& Nichols, 2010; Lent et al., 1994). In addition, a set of curriculum resources aligned with developmental need and level of career maturity is recommended as a part of this study, showing how the career development model could be implemented. With this in mind, this study describes how career education is integrated into the curriculum, and details the career development model on offer to students. Specifically this study addressed the research question: What career development model, and curriculum recommendations, can support IT students to be better prepared for life after university to achieve their graduate outcomes?

\section{Background}

The concept of the boundary-less career has been used to describe the novel career forms that are unfolding in the modern work force context. Boundary-less careers, as defined by Greenhaus et al. (2008), are those where a person moves across boundaries of separate employers during their career and draws validation and marketability of their career from outside the present employer (such as external networks). Individuals may have many and varied opportunities across their working life for multiple professional roles. It has been argued that, in addition to the concept of careers being boundary-less, careers are also protean in nature, which means they are managed by an individual, rather than by an organisation (Greenhaus et al., 2008). Watts (2005, p. 67) argued that "careers are no longer chosen, but they are constructed through the series of choices all individuals make throughout their lives". Further, during their career a person's work history impacts on accumulation of career competencies and identity (Greenhaus et al., 2008). A boundary-less and protean career outlook requires individuals to not only prepare for their career, but to engage in continual career development/career management during their life in response to changing occupational demands. 
Career development is considered an ongoing process of a person acquiring knowledge, concepts, skills and attitudes that will equip them to prepare for and manage their careers (Watts, 2006). Patton defined career development as:

" a spectrum of career related processes which include the provision of information, counselling, curriculum and program interventions such as career education, structured experiences such as work experience, and coordination of events such as career markets" (Patton, 2005, p. 219).

Career development is an activity that a person conducts during their entire life, however, without active participation in relevant career related processes during secondary and tertiary education, skills development and career aspirations may not mature (Watts, 2006). When a person is career mature they can make 'good' decisions that contribute to their career choice (Betz \& Luzzo, 1996). Preparing for a career requires a developmental approach, such as asking students to use their time at university to build their career choice along with acquisition of skills. Alongside career development, the concept of employability is often referenced when exploring how to help students prepare for the working world.

Employability can be defined as an approach towards developing a student's understanding, skills, efficacy and metacognition towards their future career (Knight \& Yorke, 2003). Enhancing a person's employability is an individual process, requiring students to self-regulate skills development towards a professional identity. There is a link between career development and employability, with the concepts going hand-in-hand in supporting an individual in their working life (Watts, 2006). A process of career development is considered important to enhance a student's ability for longer-term employability (or sustainable employability) (Watts, 2006). A process of career development can contextualise employability needs and align skills, attributes and interest with career choice (Jollands et al., 2014; Nagarajan \& Edwards, 2008; Qenani et al., 2014).

To form professional perceptions, students need to develop their employability holistically, which includes an awareness of the labour market and other social factors. This requires for example IT students to prepare for roles that may occur both within and outside of the IT profession (Palmer et al., 2018). To prepare a student's professional perception or identity, there is a need for a discipline-specific focus to career development. A discipline-specific focus will engage students with their employability towards their chosen career (Jollands, 2015). At Deakin University, career education is provided university wide as well as contextualised to the discipline.

\section{Career education in IT at Deakin University}

Higher education institutions in Australia, such as Deakin University, are required to direct career development activities within the disciplines. As defined in McKenzie et al. (2018, p. 195) "career development learning can assist students to acquire knowledge, skills and attitudes that help them make better career choices and transitions". Furthermore, career guidance can assist with the development of career management skills, enabling tertiary students to achieve the level of career maturity 
required. Deakin University currently teaches on a trimester system, with three teaching periods per year of equal duration and status. The discipline of Information Technology rests within the Faculty of Science, Engineering and Built Environment. The School of Information Technology (SIT) offers undergraduate and postgraduate IT programs. The courses offered specialize in: computer science, software engineering, networking, artificial intelligence, data analytics, cyber security and creative technology (games development, web and mobile applications). These programs are delivered in both on-campus and off-campus modes, with a focus on an industry and professional society informed curriculum, to build IT graduates.

At Deakin University the provision of career education is provided through integrated curriculum models, as described by (Watts, 2006). The DOTS model (which stands for decisions, opportunities, transitions and self) (Deakin University, 2010, 2018; Law \& Gordan, 1977) informs the construction of resources to provide career education. To implement career development at Deakin University the Graduate Employment Division have deployed a suite of resources to assist students in their career education and job seeking needs. Under the banner of 'Deakin TALENT' students can access various resources, workshops and career counsellors to help them with preparation for work after university (Deakin University, 2018). In addition, career development resources are embedded in the curriculum to build career competencies across an undergraduate student's degree program. Most recently, a career education 'core body of knowledge' curriculum plan has been provided for the students in the Faculty of Science, Engineering and Built Environment, as shown in Table 1. The curriculum plan describes that ideally students will undertake awareness objectives in Year 1 of their degree, which also incorporates the learning outcome of the explore theme. In the middle years of a degree, activities will be embedded and assessed in the curriculum for students to meet the build learning outcome. In their final year, students will be expected to meet the apply learning outcome.

Across the themes IT students engage with career development through both curriculum approaches and extracurricular activities. Further information on how the career education curriculum plan has been integrated into the School of IT is described in the next section.

\subsection{Resources to assist career development in IT}

Palmer et al. (2018) suggest various activities to assist career development such as: raising student awareness about the current job market characteristics, encouraging students to develop initial career plans, assisting their draft resumes and job applications, and experience mock interviews. Furthermore, these resources need to be embedded into the curriculum to signal importance (Palmer et al., 2018). Scott et al. (2017) used CV writing, interview preparation and job-seeking skills as a curriculum model to assist students in their career development and employability. Pordelan et al. (2021) used digital story-telling to improve students' career decision making abilities. In addition, to learning activities, Smith et al. (2017) argued that the social community surrounding an individual is an important source of career advice. They found that undergraduate students referred to a family member $34 \%$ of 


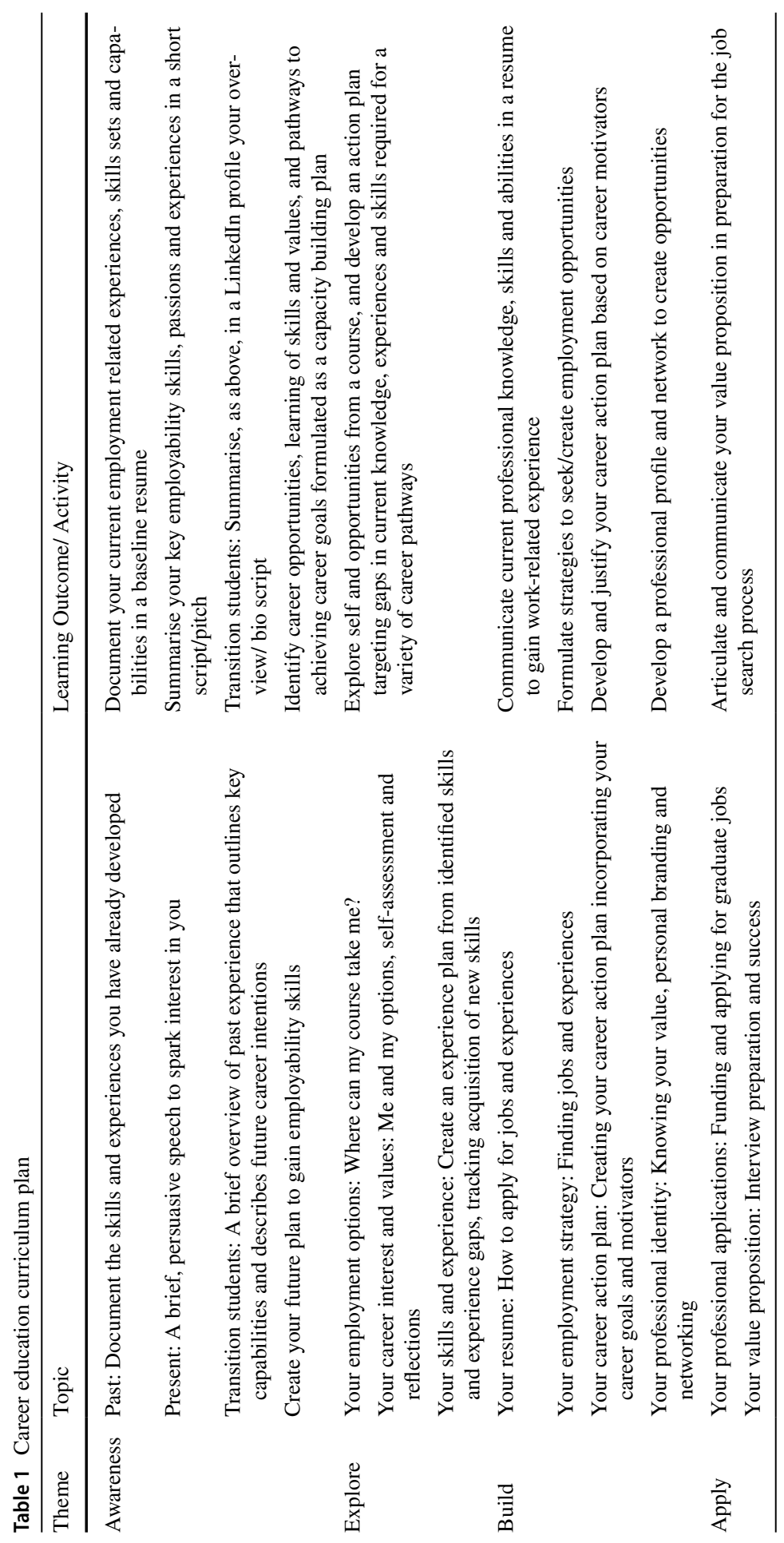


the time for career advice, they went to lecturers/tutors/career staff $26 \%$ of the time, friends, peers, other students $24 \%$ of the time, $9 \%$ referred to those in industry with the remaining not seeking advice from anyone.

When it comes to IT students, the authors of this paper have queried students at Deakin University in relation to their career development needs. To explore IT students' career development background, prior education and work experience were investigated as presented in McKenzie et al. (2018). As described in McKenzie et al. (2018) " $61 \%$ of respondents came to university from an alternative pathway (such as from Technical and Further Education (TAFE) studies), with 39\% identifying as coming to university straight from secondary school or after a short period of work experience (casual or part-time employment)" (McKenzie et al., 2018, p. 461). Further as reported in McKenzie et al. (2018) "of those who identified as coming to university from an alternative pathway, $30 \%$ reported TAFE as their highest level of education, with $21 \%$ reporting partial achievement of a university course as their highest level of education" (McKenzie et al., 2018, p. 462). For IT students in regards to current employment status, "79\% of students identified as not being employed in IT, yet 63\% had an IT industry/network connection (knew someone who works in IT)" (McKenzie et al., 2018, p. 462). In regards to who influenced students' decisions to study IT at university, " $65 \%$ reported 'myself' as the primary reason, with 'a general interest' as the second influence for studying IT" (McKenzie et al., 2018, p. 462). When it came to work experience, "82\% of students identified as having no prior work experience before coming to university" (McKenzie et al., 2018, p. 462). Further, as described in McKenzie et al. (2018) in regards to career resources, a variety of resources where being used by IT students to assist their career development. Students stated that: " $16.5 \%$ used internal online career resources, $16.5 \%$ used career activities in class, $15 \%$ asked their teachers for career assistance, $15 \%$ curated an online career portfolio, $12.5 \%$ used resume services with $13.5 \%$ not currently using any career resources" (McKenzie et al., 2018, p. 462).

Taking on board student background the School of IT at Deakin University implemented a variety of resources to provide career development learning, and to specifically address Deakin University's career education 'core body of knowledge' requirements. In summary since 2014 these resources have included:

1. A course-wide online learning platform for the delivery of IT course and career information

2. Within the above online learning platform a 'professional skills template' is provided for students to download and personalise into their own electronic portfolio

3. A set of first year subject/unit level curriculum activities that evidence the awareness, explore and build learning objectives. IT students are asked to complete a skills self-audit, experience plan, baseline resume and reflection on their professional networks

4. A set of second year subject/unit level curriculum activities that evidence the build learning objectives. IT students are asked to engage in job search techniques and to develop a career action plan. In addition, the students complete the employability self-assessment available on the Developing Employability website (Bennett, 2019) 
5. A set of third year subject/unit level curriculum activities that evidence the apply learning objective. Students are asked to develop a tailored resume and cover letter

While the DOTS model informed the construction of career education resources provided by the Graduate Employment division of Deakin University, this study argues that the best way to implement career resources is via an alternative career development model. A more suitable career development model to suit the IT student experience and best prepare them for life after university is described next.

\section{Career development model to support undergraduate IT students}

The model of career development (as shown in Fig. 1) provides a developmental approach to supporting career education, focusing on building a student's career choice through socio-cognitive activities. The model also outlines IT-specific career development resources that impact upon students' progression of their career choice. The model was informed by prior research into the IT student experience of career development as shown in McKenzie et al. (2015). In McKenzie et al. (2015) it was argued that IT students require specific career development resources, with the components of internship, community interaction, the IT discipline, and professional skills deemed critical to support their career development during their time at university. Further investigation in studies McKenzie et al. (2017a), McKenzie et al. (2017b), McKenzie et al. (2018) found that IT students lack self-efficacy in understanding the process of career development, therefore require a developmental approach to help them utilise the career development resources on offer. The developmental approach of social cognitive career theory (SCCT) was deemed best to support IT students' career development. The model supports the IT student experience by extending the well-known career development approach of SCCT, as well as outlining IT specific career resources that impact career choice. The resources described in the model were deemed most important by IT students, as outlined in (McKenzie et al., 2018). SCCT is relevant to the IT student experience because of the way in which it helps to understand the factors that affect student choice regarding career goals or aspirations.

As a developmental approach SCCT considers "individual cognitions and psychosocial states along with economic and sociological factors to understand the acquisition of career development attributes" (Lent et al., 1994, p. 80). SCCT is a derivative of social cognitive theory, as proposed by Bandura (1986). As it incorporates environmental and contextual factors, SSCT is helpful to understand an individual's career development, however further understanding is required in regards to how SCCT is applied to the discipline of IT. Overall SCCT states that "people generate career interests by developing confidence in activities related to the interests (i.e. self-efficacy) and by learning that outcomes for them are contingent on the effort expended (i.e. outcome expectations)" (McKenzie et al., 2017b, p. 16). People set related career goals and self-regulate their behaviour towards these goals as they develop their career interest (Janz \& Nichols, 2010; Lent et al., 1994). 


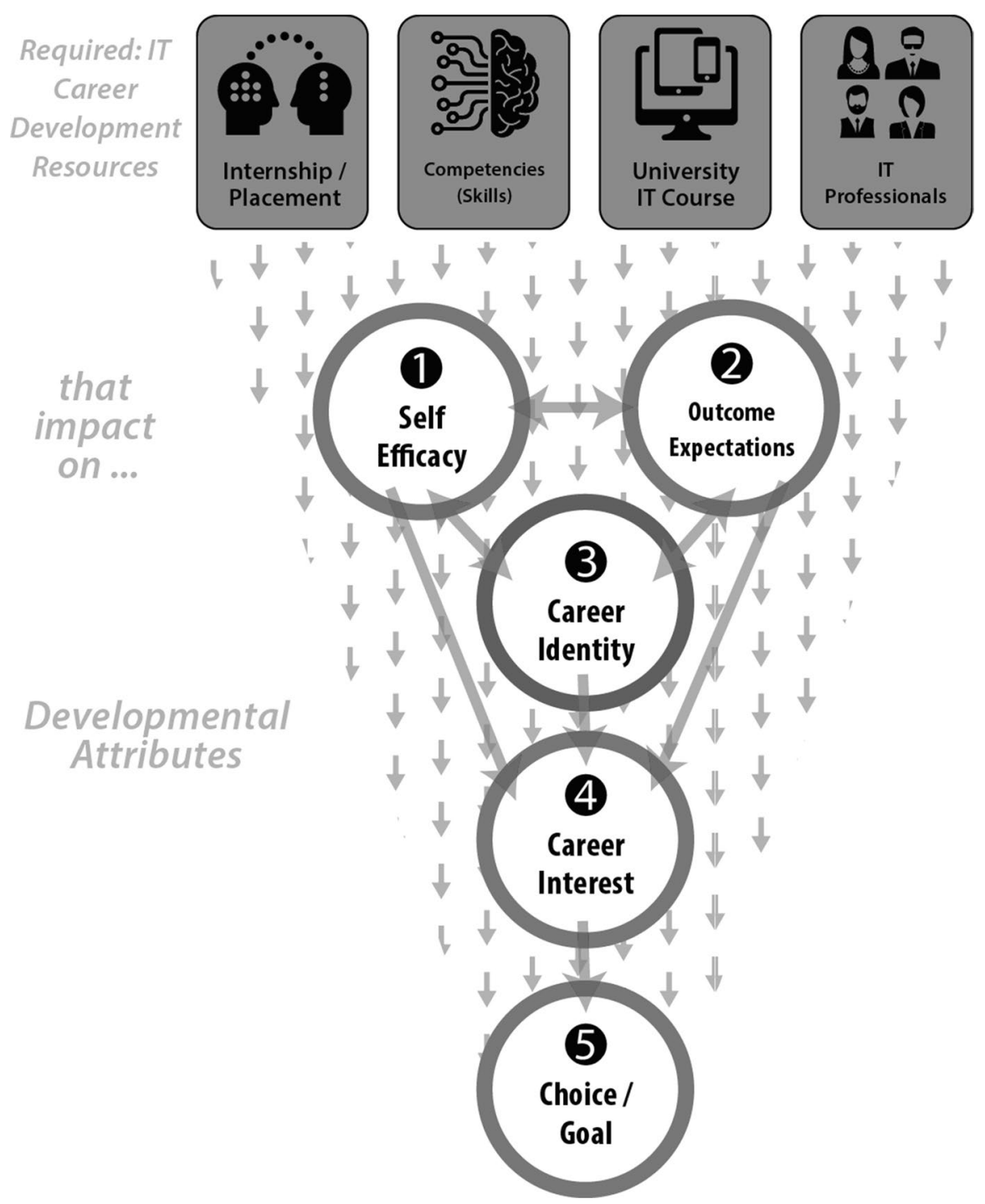

Fig. 1 Career development model to support undergraduate IT students

The career development model integrates career resources enabling the Deakin University career education core body of knowledge to be strongly linked to the student experience. In particular, the model describes, via the boxes at the top, the career development resources deemed most important by IT students. The numbered circles show the developmental attributes that students need to extend during their time at university to inform their career choice. The IT career development resources impact on the developmental attributes of the model, progressing a student's career 
choice through a variety of activities and interactions over the period of their university studies.

The original developmental attributes of SCCT are shown in the model in circles one, two, four and five. The research reported in McKenzie et al. (2014), McKenzie et al. (2015), (McKenzie et al., 2017b), (McKenzie et al., 2018) determined that career identity (circle three) is an important developmental attribute to inform IT student career choice, thus career identity was added as a developmental attribute to inform career choice/goal.

In summary, using the career development model to inform and direct curriculum development helps IT students build their self-efficacy and outcome expectations through active engagement with relevant career resources. Self-efficacy and outcome expectation act together to influence a student's career identity and interest. With an informed sense of identity, students can better relate their interest to career choice, enabling them to work towards their chosen career outlook. The developmental approach of SCCT enables a meaningful and individual approach to supporting students' career development. A focus on developmental needs will allow the model of career development to help students address barriers to their career aspirations, provide better alignment with the career resources, as well as improve their level of career maturity. The career development resources as shown in the model impact on the developmental attributes, providing tangible elements that contribute towards a student's career development. Before further description of the developmental attributes, the career development resources (shown at the top of the career development model) are described.

\subsection{IT career development resources}

The model shows the resources of influence on IT students' career development. Relevant resources interact with the developmental attributes providing opportunity for students to develop their career choice (circle five). The resources of the model are described as:

1. IT Professionals: IT students benefit from interaction with those currently working in the IT industry as a key career development resource. Such interaction can come in many forms during a student's time at university including guest lectures, networking and experiential learning. Further, access to IT professionals enables IT students to build a community and social capital (networks and relationships between people) that they can refer to when exploring their career interest and affirming their career identity.

2. University IT Course: Defined in this paper as an undergraduate study offering in IT. It provides a key way for students to engage with the discipline, and provides a general preparation for the range of areas in which an IT student could be employed (McKenzie et al., 2018). McKenzie et al. (2018) argued for discipline knowledge and skills to be of central importance to undergraduate studies to best prepare students for work in the field. A university IT course is a key 
resource to inform self-efficacy, outcome expectation and identity as it embeds and facilitates numerous career development and employability resources.

3. Competencies: A competency is known as skills, knowledge and attributes required to achieve performance standards within a field of work (Deloitte, 2017; Suleman, 2018). Competencies (skills) can also be defined as a set of generic and discipline-specific skills developed through education and work experience that contribute towards opportunities to secure a relevant job (Deloitte, 2017). A competency is composed of skills learnt from previous experiences or learning activities and the ability of the individual to self-regulate activities towards further skills development (Suleman, 2018). Joshi et al. (2010) define IT competencies in terms of three categories: technical, business and human. During their time at university, students will be developing competencies relevant for their future career, with their course providing the main opportunity for skill development. Marbach et al. (2019) found that the value students place on skill development is shaped by their higher education classroom experience. Students need to be aware of the competencies expected in job roles, and in particular be cognisant of requirements for the careers that are of interest to them.

4. Internship/ Placement: An internship, placement, or formal work is a key career development and employability resource required by IT students as described by McKenzie et al. (2018). An internship is defined as a period of work conducted within an employment setting, requiring students to actively engage in authentic workplace activities. An internship should be selected based on the opportunity it provides to expand and confirm students' career competencies, interest and identity. Numerous authors define internship as an integral component of a student's time at university as it provides an opportunity to prepare for the working world (Australian Government, 2016; Jackson, 2015; Jackson \& Collings, 2018; Koppi et al., 2010; Lucas et al., 2009; McIlveen et al., 2011). Jackson and Edgar (2019) found that students are not confident at drawing on their internship experience to assist in applying for graduate roles, demonstrating the need for internship as a part of an integrated suite of activities to assist career development.

While other resources impact upon IT students' career development, as shown in the career education approach implemented by Deakin University, the resources listed here were shown to be of most importance to the IT student cohort as shown in research conducted in McKenzie et al. (2018).

\subsection{Developmental attributes of IT students}

The developmental attributes of self-efficacy, outcome expectations, identity, and interest, as shown in the model, utilise the IT career development resources to inform the construction of IT students' career choice/goal. The developmental attributes are described as:

1. Self-efficacy: A person's belief in their ability to achieve in a specific situation or accomplish a task (Lent et al., 1994). The career development model shows 
self-efficacy as circle one. Self-efficacy informs students' decision making and impacts their self-awareness that leads to career choice (Gianakos, 1999). SCCT proposes that self-efficacy, along with outcome expectations, influences a student's career interest. Bandura (1986) suggested, building students' self-efficacy requires consideration of various behavioural, emotional and social influences. Lent et al. (2017) defined primary experiential sources of self-efficacy to be: personal mastery; verbal persuasion; vicarious learning and affect (both positive and negative), and experience in relation to career exploration and decision-making. It has been found that academic achievement can play a key role in supporting a student's self-efficacy (Janz \& Nichols, 2010; Smith, 2002), with past performance and social persuasion impacting on the ability to visualise future self and emotional states (Bandura, 1986; Lent et al., 2017). Lent et al. (2008) asserted that self-efficacy plays a large role in mediating IT students' confidence and interest. The results in McKenzie et al. (2014), McKenzie et al. (2015), (McKenzie et al., 2017b), (McKenzie et al., 2018) show that resources specific to IT students, as shown in the model, have influence on a student's self-efficacy helping to validate their career interest and choice. Pordelan et al. (2020) found that online career resources can also increase students' career confidence. While other resources are of impact on a student's self-efficacy, such as academic achievement or feedback from teaching staff, the resources shown in the model were rated highest in importance by the student cohort (McKenzie et al., 2018). In addition to resources, self-efficacy of IT students is also impacted by barriers, such as personal and emotional issues (McKenzie et al., 2015). McKenzie et al. (2015) also discussed how IT students have difficulty in defining their career development plan, highlighting a lack of self-efficacy in understanding how to build towards their career choice (McKenzie et al., 2015, 2017a). Without a strong sense of personal efficacy, students may not be able to be self-directed, life-long learners, with an informed sense of identity and the ability to influence their own aspirations (Pordelan et al., 2021; Smith, 2002).

2. Outcome Expectation: A person's personal belief about a probable outcome resulting from effort (Lent et al., 1994). The career development model shows outcome expectation as circle two. In the career development model there is a two-way connection between self-efficacy and outcome expectation, emphasising that an increase in students' self-efficacy may affect their outcome expectations, and vice-versa. Maddux et al. (1982) found that increased outcome expectations might influence a student's intention to perform a behaviour (self-efficacy). Lent et al. (2017) found that self-efficacy mediated the relationship of outcome expectation on the sources of career exploration and decision-making. Outcome expectation is influenced in the same way as self-efficacy (Lent et al., 2017). The literature suggests that undertaking work experience can be a way to form realistic expectations regarding work requirements and confirm career competencies (Dacre Pool \& Sewell, 2007; Koppi et al., 2010; Patton, 2005; Qenani et al., 2014; van der Heijde, 2014). Additionally, building social capital can inform outcome expectations. As recorded in McKenzie et al. (2018) IT students' outcome expectations regarding the labour market are still developing, due to their reliance on work experience/internship to confirm that learning gained from their course 
applies to the working world and their career outlook. The results in McKenzie et al. (2014), McKenzie et al. (2015), (McKenzie et al., 2017b), (McKenzie et al., 2018) found that IT students ask for their social capital to be developed by receiving access to IT professionals and guest lectures during their time at university. The model in Fig. 1 highlights the resources students considered more important to impact on their outcome expectation. Overall, as with self-efficacy, outcome expectations as a developmental attribute plays a critical role in mediating the development of an IT student's identity. Outcome expectation informs a student's identity by helping them relate interest towards career competencies, as well as validating experiences (such as an internship) towards their personal aspirations.

3. Career Identity: Developing a career identity is a psychosocial process (Lent et al., 2008; Super, 1980), formed through personal development and validated by external mechanisms, such as recognition of career output during work experience. The model shows career identity as circle three. The model argues that a student's career identity is built through supporting their self-efficacy and outcome expectation, with various resources influencing how this is achieved. Tomlinson and Jackson (2019) argued that a focus on developing identity can enhance the efficacy of a student's interaction with the career resources on offer. While the focus is on the development of career identity in the model, identity development should coincide with the development of student identity (Letts, 2019). During education a student will expand their identity to evolve into a graduate or professional identity, contributing to their career identity (Nadelson et al., 2015; Smith et al., 2017). Nadelson et al. (2015, p. 705) described professional identity as "the attributes, skills, knowledge, beliefs, practices, and principles, which are representative of professionals within a profession". Letts (2019) emphasised the need to provide a developmental approach to support the construction of identity, allowing students to shape their student, graduate and career identity in relation to individual need, but also simultaneously during their time at university. Identity development enables a student to understand the labour market, and build familiarity, proximity and confidence around targeted employment areas (Tomlinson \& Jackson, 2019). Smith et al. (2017) argued that academics are a resource for student identity adaptation, however the results in McKenzie et al. (2014), McKenzie et al. (2015), (McKenzie et al., 2017b), (McKenzie et al., 2018) demonstrate that IT students do not strongly value academics as a career development resource. Furthermore, as discussed in McKenzie et al. (2017b), while students may have realistic career aspirations, their plans for achieving their career goals are not clear, highlighting potential issues with identity formation due to under-utilisation of career development resources. Issues with identity formation may manifest in unstable career development plans, which may also result in dissatisfaction and lowered academic performance (Holland, 1996). Relevant career-related interventions are required to inform a student's identity (Gianakos, 1999; Scott \& Ciani, 2008), with Bennett et al. (2016) suggesting that identity development should focus on students reflecting on personal development, rather than from a skill development perspective. As argued in McKenzie et al. (2017b), McKenzie et al. (2017a) and McKenzie et al. (2018), development of an action-based career development plan that is constructed from an IT student's personal career goals, balanced within 
guidelines from the IT discipline (such as professional society guidelines), is required to assist students in aligning their motivations, interests and competencies with a career identity. If students build a strong career identity, their interest towards achieving their career goals can be maintained.

4. Career Interest: Interest is the curiosity and positive emotion students exhibit for constructing a career in IT (Janz \& Nichols, 2010). The model shows career interest as circle four. As Bennett et al. (2016, p. 18) argued, increased interest leads to "career curiosity, student engagement and capacity for creativity and problem solving, active agency in the learning domain, and motivation to learn". Lent et al. (1994) argued that the self-regulation of behaviour towards career development is a combination of self-efficacy, outcome expectations and interest all contributing towards career choice/goals. Islam et al. (2015) asserted that when a student selects their study based on interest, this interest can transform into career choice. Importantly to develop their career interest, IT students need to be motivated to self-regulate their behaviour towards their career goals (Janz \& Nichols, 2010; Lent et al., 1994). The results in McKenzie et al. (2018) demonstrated that IT students do not strongly utilise class-based or career centre resources to extend their career interest. Students' interest in studying IT at university was formed largely by self-interest, with 'myself' being the main influence on the choice to study IT. Interest was also developed by students' prior studies in IT before coming to university (McKenzie et al., 2018). This result was also found by $\mathrm{Xu}$ (2013), showing students did not acknowledge sources of cultural capital, such as family, friends and teachers, to directly impact on their career interest/choice. Rather, sources of social capital such as peers and professional networks are of influence (Xu, 2013). However, IT students surveyed and reported in McKenzie et al. (2018) described no work experience in IT prior to studying at university. This demonstrates a missed opportunity for students to build their outcome expectation and IT interest. McKenzie et al. (2018) found that IT students rely on IT professionals and their university course, rather than career resources, to build their interest and confidence in relation to their career development and employability (McKenzie et al., 2017b). Assisting students to explore their interest and self-regulate their behaviour in relation to developing their career development will help them better relate personal interest to career interest and professional roles (career identity). Overall, by supporting the development of an IT student's self-efficacy, outcome expectations and career identity, their career interest will be enhanced.

5. Choice/Goal: Career goals are defined as short-term and long-term aspirations for engaging in the working world (McKenzie et al., 2017a). The model shows choice/goal as circle five. To help with career choice it is important for students to develop their interests and skills relevant for the area/discipline that they intend to work in (MCEECDYA, 2010). As shown in McKenzie et al. (2015), McKenzie et al. (2017b) and McKenzie et al. (2017a), IT students demonstrated various career aspirations. As reported in McKenzie et al. (2015), McKenzie et al. (2017b) and McKenzie et al. (2017a), students identified several barriers to achievement of their career goals, with the most commonly reported barriers being "motivation and enthusiasm" or "confidence" related. Xu (2013) found in their study of 
university students that career choice was also impacted by monetary and nonmonetary costs and benefits, cultural and social capital. The variety of aspirations of IT students, along with barriers, demonstrates the need to develop a students' individual career identity to navigate barriers and achieve set aspirations. In addition, opportunities for personal career planning, focusing on both short and long-term action are required to assist students to articulate their career goals into reality. For IT students to establish appropriate and realistic career plans, they need to have a strong sense of labour market awareness and participate in workplace experiences (McKenzie et al., 2017a). Once students have an increased understanding of their career goals and how they can achieve these goals, they can make better use of university resources such as face-to-face and online professional development activities and employment services (McKeown \& Lindorff, 2011). The model argues that if IT students utilise career resources and have their developmental attributes supported, their career goals, and subsequent career maturity, will be progressed. This approach to career development expands on that presented by Lent et al. (2008), Smith (2002), and Lent et al. (2017). In summary, they argue that a sustained career interest can lead to informed career goals, and better academic achievement.

\section{Concluding remarks: supporting IT students}

To support university students in building upon their career choice, this paper addressed the following research question: What career development model, and curriculum recommendations, can support IT students to be better prepared for life after university to achieve their graduate outcomes? To address this question, the paper described the career development model and resources that were integrated into curriculum activities for IT students at Deakin University, showing practical ways in which career development can be integrated into the IT student experience. The model integrates IT students' needs to provide a discipline-specific yet flexible approach that ensures students can transfer IT knowledge and skills taught in their course into realistic career choices and appropriate career plans. Often university courses in IT are attempting to train students for IT professional roles that are only now emerging or do not yet exist (McKenzie et al., 2018), highlighting the need for a student to be equipped to self-manage their career to navigate the varied labour market. The career development model described in this paper builds upon SCCT by adding career identity as an important component that contributes to building students' career choice. However, the model does not explicitly state the outcome of increased career maturity, requiring a student's level of career maturity to be considered when supporting their developmental attributes. Some students may need more support to build their developmental attributes of self-efficacy, outcome expectation, identity and interest towards their career goals. Overall, the career development model and associated resources produce a more robust approach to supporting career development, promoting better graduate outcomes for students in IT.

The graduate employment outcomes for students of Deakin University has improved since the implementation of the career development model (the period 
2015 to 2018) (QILT, 2018). Specifically, there was an 8.3\% increase in regards to the measure of full-time employment for IT graduates from Deakin University QILT (QILT, 2018), with the median salary also increasing. In 2019 despite a turbulent labour market, $77.3 \%$ of IT graduates from Deakin University found full-time employment (QILT, 2020), compared to $68.7 \%$ across the sector. While other factors do come into consideration when supporting a student's career development, the integration of career resources and the career development model into the IT curriculum has been a strong contributing factor towards improved graduate outcomes.

Even though there has been an increase in graduate outcomes for IT students at Deakin University as shown in QILT $(2018,2020)$, employers are reporting that more graduates are needed to fill the jobs available (QILT, 2020). At a national level, the number of IT students are not meeting the skills demands (Deloitte, 2020). While employers appear satisfied with IT students' technical skills to achieve role requirements, it is reported that they are not satisfied with students' graduate employability (Deloitte, 2018). Tonkin (2019) describes that employers are reporting IT graduates are lacking interpersonal skills when applying for jobs. While recent graduate employment outcomes for Deakin University IT students evidence significant improvement, the results in the Digital Pulse (Deloitte, 2020) demonstrate there remains the need to provide a focus on career development for students during their time at university, to increase their ability to secure desired employment, but also have the time to build their employability skills. The need to focus on ensuring university graduates meet the skills needs of the industry can be seen worldwide, particularly in areas like the U.S. that will see over 500,000 new openings in IT by 2029 (U.S. Bureau of Labour Statistics, 2021). Worldwide national frameworks for career development continue to influence the agenda of higher education, requiring institutions to critically consider how they support the student experience to increase their graduate employment outcomes (Nghia et al., 2020). The application of the career development model in this study can be considered as an approach to support students in other institutions, taking on board contextual dynamics (Nghia et al., 2020) and student background when considering how to support career choice.

Data availability Can be provided upon request.

\section{Declarations}

Ethics approval Deakin University Human Ethics Approval Code: STEC-10-2017-Deakin University.

\section{References}

Australian Government. (2016). Australian labour market update. Department of Employment. Retrieved 19th February from https://docs.employment.gov.au/system/files/doc/other/almu_january_2016.pdf

Australian Government. (2019). Industry 4.0. Australian Government. Retrieved 24th June from https:// www.industry.gov.au/funding-and-incentives/manufacturing/industry-40 
Bandura, A. (1986). Social foundations of thought and action: A social cognitive theory. Prentice-Hall.

Bennett, D. (2019). Developing Employability Educator Site. Australian Government Department of Education and Training. Retrieved 20th of February from https://developingemployability.edu.au/

Bennett, D., Richardson, S., \& MacKinnon, P. (2016). Enacting strategies for graduate employability: How universities can best support students to develop generic skills: Part A. Retrieved 13th February from http://www.olt.gov.au/project-how-universities-can-best-support-students-developgeneric-skills-enacting-strategies-gradua

Betz, N., \& Luzzo, D. (1996). Career assessment and the career decision-making self-efficacy scale. Journal of Career Assessment, 4(4), 413-428. https://doi.org/10.1177/106907279600400405

Carbone, A., Hamilton, M., \& Jollands, M. (2015). Moving towards the future of teaching pedagogies and learning paradigms: Understanding the 21st century employability challenges in the ICT industry 9th International Conference on Researching Work and Learning RCL2015, Singapore. https:// researchbank.rmit.edu.au/view/rmit:35469

Crites, J. (1973). Career Maturity. NOME Measurement in Education, 4(2). https://eric.ed.gov/?id= ED077976

Dacre Pool, L., \& Sewell, P. (2007). The key to employability: Developing a practical model of graduate employability. Education + Training, 49(4), 277 - 289. https://doi.org/10.1108/00400910710754435

Deakin University. (2010). Improving Graduate Employability: Embedding Career Planning and Development in the Curriculum.

Deakin University. (2018). DeakinTALENT - Graduate Employment Division. Deakin University. Retrieved 23rd January from http://deakintalent.deakin.edu.au/

Deloitte. (2017). Soft skills for business success. https://www2.deloitte.com/au/en/pages/economics/articles/ soft-skills-business-success.html

Deloitte. (2018). Australia's Digital Pulse: Driving Australia's international ICT competitiveness and digital growth. Australian Computer Society. Retrieved 23rd August from https://www.acs.org.au/ content/dam/acs/acs-publications/aadp2018.pdf

Deloitte. (2020). Australia's Digital Pulse: Unlocking the potential of Australia's Technology workers. Australian Computer Society. Retrieved 26th of February from https://www2.deloitte.com/au/en/ pages/economics/articles/australias-digital-pulse.html

Farmer, H. S. (1985). Model of Career and Achievement Motivation for Women and Men. Journal of Counseling Psychology, 32(3), 363-390

FYA. (2021). The New Work Standard. Retrieved 26th of February from https://www.fya.org.au/wp-content/ uploads/2020/07/FYA-New-Work-Standard.pdf

Gianakos, I. (1999). Patterns of Career Choice and Career Decision-Making Self-Efficacy. Journal of Vocational Behavior, 54(2), 244-258. https://doi.org/10.1006/jvbe.1998.1668

Greenhaus, J. H., Callanan, G. A., \& DiRenzo, M. (2008). A boundary-less perspective on careers. In C. L. C. Julian Barling (Ed.), The SAGE Handbook of Organizational Behavior: Volume One: Micro Approaches. SAGE.

Hackett, G., \& Betz, N. E. (1981). A self-efficacy approach to the career development of women. Journal of Vocational Behavior, 18(3), 326-339. https://doi.org/10.1016/0001-8791(81)90019-1

Hall, D. (2002). Career In and Out of Organisations. SAGE Publications, Inc.

Higher Education Academy. (2015). Framework for embedding employability in higher education. Higher Education Academy. https://www.heacademy.ac.uk/knowledge-hub/framework-embeddingemployability-higher-education

Holland, J. (1985). Making vocational choices: A theory of vocational personalities and work environments. Prentice-Hall.

Holland, J. (1996). Exploring careers with a typology. American Psychologist, 51, 397-406

Islam, T., Ahmed, I., Khalifah, Z., Sadiq, M., \& Faheem, M. A. (2015). Graduates' expectation gap: the role of employers and Higher Learning Institutes. Journal of Applied Research in Higher Education, 7(2), 372-384. https://doi.org/10.1108/JARHE-05-2014-0056

Jackson, D. (2015). Career choice status among undergraduates and the influence of work-integrated learning. Australian Journal of Career Development, 24(1), 3-14

Jackson, D., \& Collings, D. (2018). The influence of Work-Integrated Learning and paid work during studies on graduate employment and underemployment. Higher Education, 76, 403-425. https://doi. org/10.1007/s10734-017-0216-Z

Jackson, D., \& Edgar, S. (2019). Encouraging students to draw on work experiences when articulating achievements and capabilities to enhance employability. Australian Journal of Career Development, 28, 39-50. https://doi.org/10.1177/1038416218790571 
Janz, B. D., \& Nichols, E. L. (2010). Meeting the demand for IT employees: Can career choice be managed? SIGMIS-CPR'10, May 20-22, Vancouver, BC, Canada. http://dl.acm.org/citation.cfm?id= 1796913

Jollands, M. (2015). A framework for graduate employability adapted for discipline differences HERDSA Research and Development in Higher Education: Learning for Life and Work in a Complex World Vol. 38, Melbourne, Australia. http://asnevents.s3.amazonaws.com/Abstrakt-FullPaper/22594-Jollands_ 22594_final.pdf

Jollands, M., Clarke, B., Grando, D., Hamilton, M., Smith, J., Xenos, S., Carbone, A., \& Burton, L. (2014). Developing graduate employability through partnerships with industry and professional associations Joint Australian Association for Research Education and New Zealand Association for Research in Education Conference, Brisbane, Australia. http://www.aare.edu.au/publications-database.php/8982/ developing-graduate-employability-through-partnerships-with-industry-and-professional-associations

Joshi, K. D., Kvasny, L., McPherson, S., Trauth, E., Kulturel-Konak, S., \& Mahar, J. (2010). Choosing IT as a Career: Exploring the Role of Self-efficacy and Perceived Importance of IT Skills International Conference on Information Systems (ICIS), St Louis, USA. http://aisel.aisnet.org/icis2010_submissions/ 154

Knight, P., \& Yorke, M. (2003). Chapter 1: Higher Education and Employability. McGraw-Hill International.

Koppi, T., Edwards, S., Sheard, J., Naghdy, F., \& Brookes, W. (2010, January 18 - 22). The case for ICT work-integrated learning from graduates in the workplace 12th Australasia Computing Education Conference ACE 2010, Brisbane Australia. http://dl.acm.org/citation.cfm?id=1862235

Ferry K. (2018). The Global Talent Crunch: Sector Perspective. Korn Ferry Management Consulting. Retrieved 24th June from https://futureofwork.kornferry.com/sector-perspective/

Law, B., \& Gordan, A. (1977). Schools, careers, and community : a study of some approaches to careers education in schools.

Lent, R. W., Brown, S. D., \& Hackett, G. (1994). Towards a unifying social cognitive theory of career and academic interest choice and performance. Journal of Vocational Behavior, 45(1), 79-122. https:// doi.org/10.1006/jvbe.1994.1027

Lent, R. W., Ireland, G. W., Penn, L. T., Morris, T. R., \& Sappington, R. (2017). Sources of self-efficacy and outcome expectations for career exploration and decision-making: A test of the social cognitive model of career self-management. Journal of Vocational Behavior, 99, 107-117. https://doi.org/10. 1016/j.jvb.2017.01.002

Lent, R. W., Jr., Lopez, A. M., Lopez, F. G., \& Sheu, H. B. (2008). Social cognitive career theory and the prediction of interests and choice goals in the computing disciplines. Journal of Vocational Behavior, 73(1), 52-62. https://doi.org/10.1016/j.jvb.2008.01.002.

Letts, W. (2019). University Employability Agendas, Targets and Strategies. In W. L. Joy Higgs, and Geoffrey Crisp (Ed.), Education for Employability: Learning for Future Possibilities (Vol. 2, pp. 21-36). Brill. http://ebookcentral.proquest.com/lib/deakin/detail.action?docID $=5884245$

LinkedIn. (2020). 2020 Emerging Jobs Report. Linkedin. Retrieved 28th of February from https://business. linkedin.com/content/dam/me/business/en-us/talent-solutions/emerging-jobs-report/Emerging_Jobs_ Report_U.S._FINAL.pdf

Lucas, W. A., Cooper, S. Y., Ward, T., \& Cave, F. (2009). Industry placement, authentic experience and the development of venturing and technology self-efficacy. Technovation, 29(11), 738-752. https:// doi.org/10.1016/j.technovation.2009.06.002

Maddux, J. E., Sherer, M., \& Rogers, R. W. (1982). Self-efficacy expectancy and outcome expectancy: Their relationship and their effects on behavioral intentions [journal article]. Cognitive Therapy and Research, 6(2), 207-211. https://doi.org/10.1007/bf01183893

Marbach, G., Hunt, C., \& Thompson, K. V. (2019). Exploring the Values Undergraduate Students Attribute to Cross-disciplinary Skills Needed for the Workplace: an Analysis of Five STEM Disciplines. Journal of Science Education and Technology, 28, 452-469. https://doi.org/10.1007/ s10956-019-09778-8

MCEECDYA. (2010). Using the Australian Blueprint for Career Development with Adults (Ministerial Council for Education Early Childhood Development and Youth Affairs, Issue. https://docs.education. gov.au/system/files/doc/other/australian_blueprint_for_career_development.pdf

McIlveen, P., Brooks, S., Lichtenberg, A., Smith, M., Torjul, P., \& Tyler, J. (2011). Career development learning frameworks for work-integrated learning. In S. Billett \& A. Henderson (Eds.), Developing learning professionals: Integrating experiences in university and practice settings. (pp. 149-165). Springer. 
McKenzie, S., Coldwell-Neilson, J., \& Palmer, S. (2015). Developing career aspirations of Information Technology students at Deakin University Research and Development in Higher Education: Learning for Life and Work in a Complex World, Melbourne, Australia 6 - 9 July 2015. http://www.voced. edu.au/content/ngv\%3A69153

McKenzie, S., Coldwell-Neilson, J., \& Palmer, S. (2017a). Career aspirations and skills expectations of undergraduate IT students: Are they realistic? Research and Development in Higher Education: Curriculum Transformation, Sydney, Australia, 28 - 30 June 2017

McKenzie, S., Coldwell-Neilson, J., \& Palmer, S. (2017b). Informing the career development of IT students by understanding their career aspirations and skill development action plans. Australian Journal of Career Development, 26(1), 14-23. https://doi.org/10.1177/1038416217697972

McKenzie, S., Coldwell-Neilson, J., \& Palmer, S. (2018). Understanding the career development and employability of Information Technology students. Journal of Applied Research in Higher Education, 10(4), 456-468. https://doi.org/10.1108/JARHE-03-2018-0033

McKenzie, S., Palmer, S., Coldwell-Neilson, J., \& Coleman, K. (2014). Understanding Career Aspirations of Information Technology Students at Deakin University IEEE International Conference on Teaching, Assessment and Learning in Engineering 8 - 10 December 2014, Wellington, New Zealand.

McKeown, T., \& Lindorff, M. (2011). The graduate job search process - a lesson in persistence rather than good career management? Education + Training, 53(4), 310-320. https://doi.org/10.1108/ 00400911111138479

Nadelson, L. S., McGuire, S. P., Davis, K. A., Farid, A., Hardy, K. K., Hsu, Y. C., et al. (2015). Am I a STEM professional? Documenting STEM student professional identity development. Studies in Higher Education, 30, 701-720. https://doi.org/10.1080/03075079.2015.1070819.

Nagarajan, S., \& Edwards, J. (2008). Towards Understanding the Non-technical Work Experiences of Recent Australian Information Technology Graduates Proceedings of the Tenth Australasian Computing Education Conference (ACE2008), Wollongong, Australia.

Nghia, T. L. H., Pham, T., Tomlinson, M., Medica, K., \& Thompson, C. (2020). Developing and Utilizing Employability Capitals: Graduates' Strategies across Labour Markets. Taylor \& Francis. https:// books.google.com.au/books?id=szPNDwAAQBAJ

Palmer, S., Coldwell-Neilson, J., \& Campbell, M. (2018). Occupational outcomes for Australian computing/information technology bachelor graduates and implications for the IT bachelor curriculum. Computer Science Education, 28(3), 280-299. https://doi.org/10.1080/08993408.2018.1541385

Parsons, F. (1909). Choosing a vocation. Houghton Mifflin.

Patton, W. (2005). Coming of Age? A review of career guidance policy and practice in Australia. International Journal for Educational and Vocational Guidance, 5(2), 217-227. https://doi.org/10.1007/ s10775-005-8801-6

Patton, W., \& McMahon, M. (2006). Career development and systems theory: Connecting theory and practice. Sense Publishers.

Pordelan, N., Hosseinian, S., \& Baei Lashaki, A. (2021). Digital storytelling: a tool for life design career intervention. Education and Information Technologies. https://doi.org/10.1007/s10639-020-10403-0

Pordelan, N., Sadeghi, A., Abedi, M. R., \& Kaedi, M. (2020). Promoting student career decision-making self-efficacy: An online intervention. Education and Information Technologies, 25(2), 985-996. https://doi.org/10.1007/s10639-019-10003-7

Qenani, E., MacDougall, N., \& Sexton, C. (2014). An empirical study of self-perceived employability: Improving the prospects for student employment success in an uncertain environment. Active Learning in Higher Education, 15(3), 1-15. https://doi.org/10.1177/1469787414544875

QILT. (2018). 2017 Graduate Outcomes Survey National Report. Australian Government Department of Education and Training. Retrieved 27th August from https://www.qilt.edu.au/docs/default-source/ gos-reports/2017/2017_gos_national_report_final_accessiblea45d8791b1e86477b58fff00006709da. pdf?sfvrsn=ceb5e33c_4

QILT. (2020). 2020 Graduate Outcomes Survey: Short-term graduate outcomes in Australia. Australian Government Department of Education and Training. Retrieved 28th February from https://www.qilt. edu.au/docs/default-source/gos-reports/2020-gos/2020-gos-national-report.pdf?sfvrsn=be0bec3c_2

Samarasekera, I. (2012). How Can Higher Education Reconcile Its Different Missions and Roles? Conference on Institutional Management in Higher Education (IMHE) 17-19 September, Paris.

Scott, A. B., \& Ciani, K. D. (2008). Effects of an Undergraduate Career Class on Men's and Women's Career Decision-Making Self-Efficacy and Vocational Identity. Journal of Career Development, 24(263). https://doi.org/10.1177/0894845307311248 
Scott, F. J., Connell, P., Thomson, L. A., Willison D. (2017). Empowering students by enhancing their employability skills. Journal of Further and Higher Education 1-16 https://doi.org/10.1080/ 0309877X.2017.1394989

Smith, S., Smith, C., Taylor-Smith, E., Fotheringham, J. (2017). Towards graduate employment: exploring student identity through a university-wide employability project. Journal of Further and Higher Education 1-13 https://doi.org/10.1080/0309877x.2017.1390077

Smith, S. M. (2002). The role of social cognitive career theory in information technology based academic performance. Information Technology, Learning, and Performance Journal, 20(2), 1-10

Suleman, F. (2018). The employability skills of higher education graduates: insights into conceptual frameworks and methodological options [journal article]. Higher Education, 76(2), 263-278. https://doi.org/10.1007/s10734-017-0207-0

Super, D. E. (1980). A life-span, life-space approach to career development. Journal of Vocational Behavior, 16(3), 282-298. https://doi.org/10.1016/0001-8791(80)90056-1

Tomlinson, M., \& Jackson, D. (2019). Professional identity formation in contemporary higher education students. Studies in Higher Education(Sept 2019). https://doi.org/10.1080/03075079.2019.1659763

Tonkin, C. (2019). The tech talent shortage is real: Businesses want a very particular set of skills. ACS. Retrieved 2nd November from https://ia.acs.org.au/article/2019/the-tech-talent-shortage-is-real. html?r

U.S. Bureau of Labour Statistics. (2021). Occupational Outlook Handbook: Computing and Information Technology. United States Department of Labour. Retrieved 22nd of April from https://www.bls. gov/ooh/computer-and-information-technology/home.htm

van der Heijde, C. M. (2014). Employability and self-regulation in contemporary careers. Psycho-social Career Meta-capabilities, 2014(Dynamics of contemporary career development), 7-17. https://doi. org/10.1007/978-3-319-00645-1_1

Watts, A. G. (2005). Career Guidance Policy: An International Review. The Career Development Quarterly, 1(September 2005), 66-76. https://doi.org/10.1002/j.2161-0045.2005.tb00142.x

Watts, A. G. (2006). Career development learning and employability. The Higher Education Academy.

Xu, Y. J. (2013). Career Outcomes of STEM and Non-STEM College Graduates: Persistence in MajoredField and Influential Factors in Career Choices [journal article]. Research in Higher Education, 54(3), 349-382. https://doi.org/10.1007/s11162-012-9275-2

Yorke, M. (2004). Employability in higher education: what it is - what it is not (Learning \& Employability: Series One, Issue. http://www.employability.ed.ac.uk/documents/Staff/HEA-Employability_ in_HE(Is,IsNot).pdf

Publisher's Note Springer Nature remains neutral with regard to jurisdictional claims in published maps and institutional affiliations. 